\title{
Public versus private water delivery, remunicipalization and water tariffs
}

\author{
Bel, Germà †S* \\ (Forthcoming Utilities Policy)
}

† Universitat de Barcelona, Departament d'Estadística, Econometria i Economia Aplicada, John Keynes 1-11, 08034 Barcelona, Spain.

$\int$ Observatory of Analysis and Evaluation of Public Policies, Universitat de Barcelona.

John Keynes 1-11, 08034 Barcelona, Spain

(*corresponding author): Germà Bel gbel@ub.edu

\begin{abstract}
Evidence regarding the drivers and the effects of remunicipalization remains in short supply. In this paper we exploit existing analyses of earlier historical phases of the remunicipalization of water delivery services to disentangle the role played by a range of different factors - most notably overpricing and corruption under private ownership - in the decision to remunicipalize these services. Additionally, we discuss what the effects of remunicipalization might be in the light of the, as yet, somewhat sketchy evidence. In the specific case of water tariffs, our analysis casts some doubt on whether the initial price reductions introduced following remunicipalization are sustainable over time.
\end{abstract}

Keywords: Privatization; Remunicipalization; Water service; Water tariffs

Declarations of interest: None 


\section{1.- Introduction}

While privatization of local public services, including that of water distribution, was a prevalent policy in the last decades of the past century and the beginning of the current one, in recent years remunicipalization has become a controversial policy issue. Remunicipalization has affected a wide array of services and countries, particularly -but not only-in the European Union. Its relevance has led some scholars to suggest that such process is a rebalancing in the roles of the private and the public sectors in the delivery of public services (Bönker, Libbe and Wollmann, 2016; Wollmann, 2016, 2018), while other scholars argue that remunicipalization is a complete reversal of the privatization trend prevalent in the past decades (McDonald, 2018).

Together with energy, local water services have probably been the field in which remunicipalization has given rise to most debate and most policy action (Hall, Lobina and Terhorst, 2013). After preliminary cases of water remunicipalizaton (i.e. Tucumán, Argentina) at the end of the past century, several instances of remunicipalization were initiated at the beginning of the current century, above all in Latin America. In 2000, for example, the service was remunicipalized in the Bolivian city of Cochabamba (Nickson and Vargas, 2002; Slattery 2003) and, in 2005, in the Bolivian city of El Alto-La Paz. In both cases, the service had been privatized a few years earlier. In 2005, also, the water service in the main cities of the Argentine province of Santa Fe was re-nationalized, and shortly afterwards the same occurred in Buenos Aires and Córdoba (Manzetti, 2016). Since then, during the last ten years, dozens of cities have remunicipalized their water services. Among the factors most consistently raised to justify the remunicipalization of water services are disappointment with the results of privatization, the prices charges for the service under private delivery, and claims of corruption and political favoritism.

In this paper, we seek to disentangle the extent to which each of these factors has triggered the debate and steps towards remunicipalization. To do so, we deem it essential first to review the public vs. private delivery debate, and more particularly what we already know about prior remunicipalization processes in history. To this end, we discuss how alternative theoretical approaches explain the municipalization of local public services back in the socalled Progressive Era in the US, and in the same historical period in Europe. Because we focus on local government services delivery, which is a downstream focus, we do not analyze the upstream segment of each service, as this analysis is beyond our main objective.

Next, we briefly present and discuss existing evidence regarding the results of privatization, specifically in the domain of water services. The empirical strategy we follow to this purpose does not involve a full review of the existing evidence, but to focus on the already available literary and statistical meta-analysis already available in the literature (Bel and Fageda 2007, 2009, 2017; Bel, Fageda and Warner, 2010; Bel and Warner 2008), as well as more recent studies that provide additional insights.

If disappointment with the outcomes of privatization is a driver of remunicipalization, it is of interest to analyze the empirical evidence, however scarce, on the drivers and effects of this process. To this purpose, we briefly review and discuss all the all the multivariate empirical works on drivers and effects of remunicipalization that we have been able to find in the literature, or available elsewhere. This discussion serves as the backdrop against which we discuss future prospects for remunicipalization and, more specifically, what the likely effects on water tariffs will be in the short run as well as over a longer time horizon. 


\section{2.- Municipalization in retrospect}

\section{Municipalization of public utilities}

In one of the most exhaustive analyses of the municipalization of public services, Gómezlbáñez (2003) studied the history of the municipalization of public services in the United States during the Progressive Era (Lough, 2016). His analysis found that during the initial phase - towards the end of the 18th century and the beginning of the 19th century - the private sector led the way in the construction of water, gas and, later, electricity networks. However, the second phase - initiated in the middle of the 19th century - was characterized by a progressive increase in the participation of local governments in the delivery of these services.

This increase in public sector participation did not follow a univocal trend. In already wellestablished sectors, characterized by substantive physical supply networks, such as water, governments municipalized private companies that were already providing the service. At the beginning of the 20th century, the expansion of public delivery had become a common feature in all local services in the United States, but the role of government delivery diverged according to the type of service.

The tendency to increase public ownership of energy supply was quite remarkable at the end of the 19th century and the beginning of the 20th century (Werner, 1997). However, public ownership never reached a hegemonic position: in 1920 it did not exceed 30\% in the electricity sector; in the gas sector, the share of public ownership, which before 1890 was less than 1\%, reached a maximum of 9.5\% in 1910 (Troesken and Geddes, 2003: 376), and in the following decade it fell to $4.5 \%$.

Data provided by Melosi (1981) for solid waste collection show that, in 1880, just before the municipalization process intensified, a third of the cities operated a public service. However, by the end of the first quarter of the 20th century, two thirds of cities had public production, while the participation of private firms fell correlatively. More interesting to note is that municipalization was more intense in those cities in which the service had been subject to both private provision and production. However, in the case of cities in which the provision was public (municipal) and production was assigned to external companies (usually private), the practice of municipalization was less intense.

\section{Municipalization of water services in the US}

Historical information about the water supply service is especially rich, as can be seen in Gomez-Ibañez (2003) and Melosi (2012). Table 1 shows the changes that occurred in the United States in the period from the beginning of the 19th century to the first fifteen years of the 20th century. At the end of the 18th century and during the first quarter of the 19th century, the hegemony of private enterprise was indisputable: only one of the seventeen existing networks was publicly owned. Yet, as the middle of the 19th century approached, the intervention of the public sector in the construction of new networks increased and it became hegemonic before 1875 , to the detriment of the private sector. 
Table 1 Ownership of water networks in the United States (1880-1915)

\begin{tabular}{lrrrrr}
\hline Year & $\begin{array}{c}\text { Water networks } \\
\text { (total) }\end{array}$ & $\begin{array}{c}\text { Privately owned } \\
\text { networks }\end{array}$ & $\begin{array}{c}\text { Share (\%) of } \\
\text { private firms }\end{array}$ & $\begin{array}{c}\text { Publicly owned Share (\%) of } \\
\text { networks }\end{array}$ & $\begin{array}{c}\text { Sublic firms } \\
\text { pubs }\end{array}$ \\
\hline 1800 & 16 & 15 & 93.75 & 1 & 6.25 \\
1825 & 32 & 27 & 84.4 & 5 & 15.6 \\
1850 & 83 & 50 & 60.2 & 33 & 39.8 \\
1875 & 422 & 195 & 46.2 & 227 & 53.8 \\
1890 & 1,878 & 1,072 & 57.1 & 806 & 42.9 \\
1896 & 3,179 & 1,489 & 46.8 & 1,690 & 53.2 \\
1915 & 4,440 & 1,395 & 31.4 & 3,045 & 68.8 \\
Source: Based on Gómez-1báñez (2003: 160) & & & & \\
\hline
\end{tabular}

Between the years 1875 and 1890 there was a new boom in the private sector, but this was only a transitory phenomenon. Jacobson and Tarr (1995) attribute it to the temporary effect of the major financial restrictions imposed on the municipalities by the federal governments following the panic triggered by a succession of bankruptcies of municipal debt bonds in 1873 (Cutler and Miller, 2005). With the lifting of these restrictions, at the end of the 19th century, the tendency for public ownership to increase reemerged, and in the second decade of the 20 th century, almost $70 \%$ of the water supply networks were publicly owned. By the mid-20th century, the boom in public ownership was such that the new distribution networks were publicly owned from the outset.

The municipalization of private companies already operating in this sector was key for the public sector to achieve hegemony in the last decade of the 19th century. According to Gómez Ibáñez (2003: 384), in 1897, only nine of the 40 largest cities in the United States maintained private ownership in the water supply system, while in 19 of them ownership had been transferred to the public sector, and in a further 12 it was the public sector that had originally created the companies. If we focus solely on the largest cities, the services of 10 of the 11 with a population of more than 300,000 inhabitants in 1900 were in the hands of the public sector, with just one city continuing to deliver the service privately (Jacobson and Tarr, 1995).

\section{Municipalization of water services in Europe}

In Europe, during the 19th century, the intervention of private companies in the management of local public services, especially in those of water supply, was not as great as in the United States. Certainly, in many countries private companies had been created to initiate the production of the service. Tynan (2001) reports on the participation of private companies in the supply of water in London in the 19th century. At the end of the 18th century, around 1782, a private company obtained the service concession in Paris.

More generally, the creation of water networks in Europe was first initiated in England during the late 18th century. Expansion of waterworks in the first quarter of the 19th century was characterized by the important role played by private firms, although public management was also increasing (Millward, 2007). After the passing of the Public Health Law, in 1848, public ownership quickly expanded and gained hegemony, making municipalization in 
England something of a precursory policy. The expansion of water networks was promoted in Germany by English engineers from the second quarter of the 19th century, but in this case the public sector had absolute hegemony in ownership and management of networks (Barraqué and Kraemer, 2014), with some exceptions, most notably Berlin, where a private concession was awarded in 1856 (Roth, 1987).

In France, private companies played a highly relevant role from the early stages of the development of waterworks, and, as in other countries, the concession model generated much criticism and acrimony from the middle of the 19th century. However, municipalization was not the most frequent response. Christelle Pezon (1999, 2010, 2012) shows that the concession model was replaced with lease and management contracts, in which large investments were made by the public sector, while private firms provided minor investments and took responsibility for system operation and maintenance. By the end of the 19th century, however, many new water systems in France had been created by local governments and were managed in-house (Pezon, 2012: 57).

In Belgium, the initial investment in the supply network was made around 1850 and originated from private companies (Aubin, 2003). In Spain there exist relevant experience of private participation in the management of their water supply services, but municipalization was less intense than in other European countries and did not begin until well into the 20th century (Núñez Romero-Balmas, 1996). However, in most European countries, the public sector imposed itself more quickly, and private enterprise was relegated to a position of secondary importance. Millward (2007: 119) provides data on the municipal share of ownership in water networks in the main European countries at the beginning of the 20th century. This information shows that in Denmark and Sweden all waterworks were publicly owned, followed by Italy (90\%) and the United Kingdom (80\%). At the other end of the ownership spectrum, in Spain only $5 \%$ of waterworks were publicly owned, making it the only country in which private ownership was hegemonic.

\section{3.- Theoretical approaches and explanations of municipalization of local public services}

The public interest approach: market failures

Public interest theory accounts for the rise of municipalization in terms of the need to safeguard public interest against the possibility of market failures. The monopolistic nature of services such as water supply, sanitation or the energy sector has been used to justify public ownership. Generally, the public interest approach emphasizes the difficulties of extending services throughout the city, especially to its least populated areas and, given that private companies find it unprofitable to extend a service beyond a certain point, there is typically under-provision.

Jacobson (2000) conducted a study of the historical evolution of water service provision in Boston, San Francisco and Seattle, and found that it was precisely private companies that initially launched this service in each city. However, at the end of the 19th century, the public sector took over service delivery. What is more interesting, however, is that in each case, as the author points out, an identical event occurred: following public intervention there was a significant increase in investment. Other cities such as New York, Baltimore, Houston and Los Angeles also recorded an increase in investment following public intervention and the municipalization of the service. For Jacobson, these experiences serve as a model for 
understanding the expansive attitude of the local public sector. In their efforts to persuade private companies to provide adequate services and to make the investments that urban growth required, municipal governments faced many problems in relation to the prevailing financial and contractual conditions. For this reason, many cities chose to municipalize the service.

It was in the big cities that the demand for services increased first and, therefore, where investments for the expansion and/or construction of the supply network were made. The fact that it was precisely in the big cities that municipalization received its first boost can be attributed to the fact that deficient investment on the part of the private sector failed to satisfy demand, a fundamental motive for opting for public delivery (Cutler and Miller, 2005). Against this backdrop, the significant growth in public finances at the end of the 19th century and the circulation of public bonds help explain the subsequent progress enjoyed by municipalization.

Yet, there are other reasons that help explain the municipalization process: including, the existence of notable external effects (or externalities) associated with such services as water and sanitation, or street cleaning and waste collection. These positive external effects impact society's health and environmental pollution. Yet, private companies do not have the mechanisms to benefit from these external effects, which is why they had little incentive to extend their services. The combination of these factors, together with the existence of economies of scale and economies of density in the production of services, generated a sizable space for the public sector to intervene.

It should, however, be borne in mind that the existence of reasons justifying public intervention does not necessarily mean that these services have to be produced by local government. If the aim is to comply with the objectives set, it is possible to adopt alternative systems such as regulation. Yet, a possible explanation for favoring public ownership as an instrument for the control of local services - as opposed to regulation - would seem to lie in the European tradition for public intervention, which typically favors public companies and the direct production of services. Hence, there is a tendency to promote municipal ownership rather than other interventions, such as the allocation of public subsidies to private companies not subject to public control. In the United States, however, the extension of the public production of local services is not easily explained by recourse to a national tradition of intervention, since the US has traditionally been inclined to regulate private monopolies and implement antitrust policies. This raises the question as to why the municipalization of companies increased to such a degree, when regulation was an equally viable option.

\section{The private interest approach: government failures}

Those scholars that adhere to the theory of public intervention based on private interests [building on insights from the seminal studies by Stigler (1971), Posner (1974, 1975) and Peltzman (1976)] do not share the idea that politicians act in order to favor public interest or improve social welfare. On the contrary, they prefer to address this question from the perspective that, via their actions, politicians are self-seeking and strive, moreover, to win political support. In this framework, a number of recent studies have sought to demonstrate that municipalization is rarely the result of the existence of market failures. 
Troesken (1997) and Troesken and Geddes (2003) claim that the frequency of public ownership in the energy sector (electricity and gas) has been much lower than that in water supply. This has come about despite the fact that in both sectors the cost characteristics of the natural monopoly are basically the same. According to these authors, if both sectors are characterized by natural monopolies, it makes little sense to forward reasons of market failure when trying to explain municipalization. Troesken and Geddes (2003) take the disparities in public ownership between the energy sector and water as a reason for invalidating the arguments based on market failure, and Cutler and Miller (2005) subscribe to this same point of view.

However, the conclusion reached by these authors is not necessarily correct. It might be that the difference between the shares of publicly owned companies - water, on the one hand, and gas and electricity, on the other - is compatible with the natural monopoly conditions of each sector. Certainly, in both sectors there are networks that make duplicity inefficient. Yet, it is also true that the energy sector has business segments, such as generation and commercialization, in which competition is possible, something that does not occur in the case of water. Thus, the difference in public intervention quotas between one sector and the other may well reflect the greater shortage of competition in the water sector, which is consistent with a greater share of public intervention in water, in line with the interpretation based on public interest theory.

In rejecting arguments of health-related externalities, Troesken (1999) alludes to the fact that investment in filters to prevent typhus and other diseases derived from water pollution was the same or even greater in the case of private companies than in that of public firms. Troesken and Geddes (2003) consider these data as proof of the lack of capacity of the externalities argument to explain municipalization.

Interestingly, evidence offered by the author himself (Troesken, 1999, 2001) provides support for the externalities argument. Based on the fact that public ownership does not mean a greater investment in filters, Troesken (2001) concludes that the main reason explaining why water companies were under public ownership was the transfer of income from taxpayers to users, since water prices were, on average, $24 \%$ lower in public companies than in private companies. Yet, the reduction in the price of water can be interpreted as a positive investment in the health field, favoring the consumption of those urban population groups with lower purchasing power and, as such, promoting an improvement in hygiene. The lower prices charged by public companies might well reflect the objective of providing access to the water network and making consumption available to the most impoverished sectors of the population.

Additionally, the evidence provided by Troesken (2002) also points to the fact that the improvement in service conditions for black communities was much greater in the case of public companies. The author argues that the quality gap between black and white communities narrowed much more rapidly in the case of public water companies. Likewise, the decrease in typhoid diseases in black communities was much more marked in the case of public delivery. In contrast, in the case of services with weaker links to health externalities such as energy and gas - there were no such differences between public and private companies in terms of quality of services provided to black communities.

Finally, Troesken and Geddes (2003) add that the public ownership of gas companies was more frequent in medium or small cities (Troesken, 1997), which is inconsistent with the 
argument of imperfections in the capital market (Troesken and Geddes, 2003). Were it to have been true, and given the difficulties private companies faced to obtain greater resources to carry out their heavy investments (while local governments enjoyed better facilities to obtain financing), it would have been logical for the public sector to have developed more in big cities, where municipal financing capacity and the need for investment have traditionally been greater. Therefore, the more frequent participation of the public sector in medium or small cities would be inconsistent with the argument of the financial restrictions on the private sector as a justification for municipalization.

However, Troesken and Geddes (2003) fail to take into account that a fairly plausible explanation for the fact that public sector energy companies have a greater presence in small or medium-sized cities is that the potential for competition between gas and electricity (partial substitutes) is much greater in big cities, and smaller in the rest. Therefore, market failure would increase in intensity as the size of the city decreases, while the reduced presence of public companies in large cities is consistent with the public interest explanation. Moreover, the historical evidence discussed above in relation to water service delivery - in which there is no room for competition - shows that public ownership, in this case, was more frequent in large cities.

The analyses that aim to refute the theories of public interest, although based on suggestive arguments and applications, are not entirely convincing. However, they do make it clear that a focus on public interest alone does not explain, once and for all, the preference for public property or its hegemony. To obtain a more complete and satisfactory explanation of the municipalization process, an additional perspective needs to be added: namely, that related to the problems derived from incomplete contracts and transaction costs.

\section{Incomplete contracts and transaction costs: useful complements for the public interest approach}

According to Gómez-lbáñez (2003: 157-158), in the first phase of the implementation of these services, then controlled by private companies, local governments were unaware of the limits that competition would have on them, and so they entered into long-term contracts with very ambiguous rules - when, in fact, these existed - dictating the obligations of private companies in relation to the quantity and quality of the services provided and their price. After these initial experiences, contracting agreements became more detailed and included more specifics; however, they quickly became obsolete because of rapid technical progress and intense urban growth.

In the second phase of the expansion of these services, the supra-municipal organizations i.e. the provinces or states - became directly responsible for the regulation and supervision of services related to the energy sector (Gómez-Ibáñez, 2003), while the municipalities continued to play a more important role with respect to the supply of water and sanitation, and the collection of solid waste. This particular trend developed at the end of the 19th century, and for this reason, regulated services at the supra-municipal level, such as energy, experienced lower levels of public ownership; in contrast, this type of ownership became much more important in services subject to direct municipal control, such as water and the collection of solid waste.

Municipalization was not the result solely of factors related to cost structures and technological change. Additionally, according to Jacobson (2000), the reluctance and lack of capacity of municipal governments to regulate and impose restrictions on private producers 
and consumers were also factors that affected municipalization. On the one hand, the regulation of private operators must have been a highly complex task during the 19th century. Troesken and Geddes (2003) report that the frequency of judicial suits was three times greater in the case of private companies that were later municipalized than for those that were not. Any interpretation of this situation is, of course, ambivalent. Indeed, Troesken and Geddes suggest that these lawsuits could also form part of municipal strategies to instigate expropriations. In short, we must choose between one of two interpretations regarding the frequency of lawsuits: 1) they reflect objective problems of interaction within a framework of incomplete contracts; or 2) we are witnessing attempts by local politicians to initiate expropriations. In the absence of any further empirical evidence, any opinion depends on the researcher's particular views regarding the motivations and incentives of politicians. Whatever the case, and whatever the real cause, it should be borne in mind that frequent litigation represents a significant added cost to the general cost of the production of services.

Moreover, the exploitation of these services by private companies was often associated with episodes of the corruption of municipal officials by private operators (Melosi, 1981). The analysis undertaken by Adler (1999) indicates that the street cleaning services in the city of New York in the 19th century were in the hands of private companies in the period 18231826, produced publicly between 1826 and 1840, returned to the private sector from 1840 to 1881 , before becoming public again after 1881 . The main factors leading to these changes were their excessive costs under public production and dissatisfaction with the results provided by the private companies, and especially the impossibility of sanctioning effectively the episodes of corruption that arose from the contracting process and the application of contracts. For these reasons, the municipalization of services was seen as the best way to avoid corruption in local politics.

In summary, the explanation of municipalization from the perspective of public interest reflects the network characteristics of many local services, the problems encountered in relation to investments derived from their natural monopoly status, the failures of the capital market and the existence of major externalities. Public intervention was much greater in services such as water, in which problems of competition were especially acute. Public ownership and municipalization were adopted more frequently in those services in which market failures were greatest, transaction costs were highest, contracts were most incomplete, and the responsibility for public intervention had been vested in local governments (more so than in the supra-municipal authority).

All in all, it is conceivable that with regards to public ownership (compared to private enterprise) it was easier to make services mandatory - the cases of drinking water and waste collection - and to allocate subsidies from the public budget for their financing (GómezIbáñez, 2003: 79). In the case of electricity and gas, there was greater room for competition and for substitution (for example in public lighting), externalities were relatively insignificant, and responsibility for the service was assumed by supra-municipal governments. All these factors help explain why public ownership was lower in the production of energy services, and public intervention made much greater use of regulation.

\section{4.- Privatization: Drivers and effects}

Seen over a longer time horizon, the prominence that the privatization of public services enjoyed in the last quarter of the 20th century and the beginning of the current one could have been a reversal of the progressive movement unleashed roughly one century earlier. 
Increasing criticism of the consensus around public interest theory as a driver of public intervention, together with increasingly disturbing evidence regarding the results of government intervention [recall once again contributions by Stigler (1971), Posner (1974, 1975) and Peltzman (1976)], paved the way for a cyclical reversal in the balance between public and private solutions to the pseudo-market of public service provision.

The privatization of public services has been a controversial issue that has triggered a substantial number of analyses seeking empirical evidence on its drivers and effects. In what follows, we first discuss briefly the available evidence on factors explaining privatization, before turning to focus on what is known about its effects.

\section{Drivers}

Economic-related factors are the main drivers of the privatization of public services, in particular, the pressure from fiscal restrictions and the search for efficiency improvements. Fiscal constraints appear as influential factors in most early studies conducted for US municipalities and for multi services (Bel and Fageda, 2007), but they are not so clear in oneservice studies. Further research (see Bel and Fageda, 2017) expanded this evidence for Europe - using different indicators of fiscal constraints and more robust techniques - and a positive influence of financial and budgetary constraints on privatization is a common outcome, regardless of the region or the set of services (single versus multi) for which the study was undertaken.

In the case of efficiency (related that is to the objective of making cost savings), two issues are of particular importance. One of them is the scale of operations at which the specific service was operated. In order to exploit scale economies, small municipalities benefited more from privatization, and early studies, particularly for the solid waste sector, tended to find a negative relationship between privatization and population (Bel and Fageda, 2007). However, more recent studies have tended to find a positive relationship, a change explained by Bel and Fageda (2017) in relation to the fact that transaction costs for small municipalities implementing privatizations might be relatively higher. Indeed, the empirical evidence generally confirms the negative relationship between transaction costs and privatization. Moreover, larger municipalities typically have better managerial capabilities to handle this type of reform process, while small municipalities have increasingly come to adopt alternative mechanisms (to privatization) to exploit scale economies, such as inter-municipal cooperation (Bel and Warner, 2016), with positive results (Bel and Warner, 2015, Bel and Sebö, forthcoming). In the more recent literature, the search for economic efficiency has also been tested by considering the level of market competition that would make efficiency improvements and costs savings more likely (i.e. Hefetz, Warner and Vigoda-Gadot, 2012; Hefetz and Warner, 2012).

As well as questions concerning fiscal constraints and economic efficiency, factors related to politics have also been studied in the literature. In this regard, since the meta-analyses conducted in Bel and Fageda (2007, literary; 2009, meta-regression), it is customary to distinguish between political interests and ideological decisions. The former refers to the partisan objectives of seeking support to stay in office, by promoting, for instance, the preferences of the closest interest groups. Frequent findings in this regard are that political interests are particularly significant in small municipalities as well as in the wealthiest municipalities. As for the influence of trade unions, although most studies analyzing this question have issues of endogeneity, Bhatti et al. (2009) find evidence of a negative 
relationship between public employees and privatization, after addressing, that is, the endogeneity of the former.

In the case of ideological attitudes, the ideology of local government had no apparent influence on the privatization decision in most studies (Bel and Fageda, 2007). This has also been the general trend reported in most recent studies analyzing the role of ideology. However, a non-trivial number of studies have recently challenged that finding (Bel and Fageda, 2017). Particularly interesting in this regard is the division drawn in studies for Scandinavian countries (i.e. Petersen, Houlberg and Christensen, 2015) between technical services - such as roads and refuse collection - and social services - such as primary schools and care for the elderly. Within this context, the privatization of technical services seems to be little influenced by ideology, while the privatization of social services appears to be ideologically driven (i.e., Elinder and Jordahl, 2013; Petersen, Houlberg and Christensen, 2015; Guo and Willner, 2017).

\section{Effects (with special reference to water privatization)}

The effects of the privatization of public services has been a much contested and widely studied question. While early studies tended to report cost savings with privatization, particularly in the delivery of such technical services as solid waste management and bus transport, the overall evidence does not indicate systematic cost savings with private production, as shown in the meta-analyses conducted by Bel and Warner (2008) and by Bel, Fageda and Warner (2010). Petersen, Hjelmar and Vrangbæk (2018) report more recent evidence, and their analyses suggest that cost savings were more frequent in older studies than in newer ones - as noted in Bel, Fageda and Warner (2010). Furthermore, they find that cost savings were more likely to appear for technical than for social services.

Beyond these general results, here, we are particularly interested in evidence related to water services. In this regard, there is mounting evidence for different aspects of the service, including efficiency, prices, accessibility and quality, as shown by the literature reviewed in Bel and Warner (2008) and Bel, Fageda and Warner (2010) - focused particularly on private management and efficiency - and the more recent and broader reviews undertaken by González-Gómez and García-Rubio, (2018), Porcher and Saussier (2018), and Silvestre, Marques and Gomes (2018), which address other dimensions of the service.

The actual costs of water services are extremely difficult to identify, as private companies are reluctant to supply this information (production costs), and more often than not users pay direct to the water company, which means data on total payments to the producer (service costs) are not usually available. For this reason, efficiency has been the main proxy for analyzing potential cost differences between public and private water delivery. And in that regard, it is a well-established outcome in the literature that efficiency does not differ significantly between private and public management. A non-trivial fraction of studies actually reports greater efficiency with public management. Indeed, the lack of superiority demonstrated by private management has been quite evident since the very first empirical studies analyzing the productivity of water by management type, as reported and discussed in Bel and Warner (2008) and statistically analyzed in Bel, Fageda and Warner (2010). Note, however, that the performance of public management in developing countries appears to be slightly worse than in developed countries, compared to private management (Carvalho, Pedro and Marques, 2015; Cetrulo, Marques and Malheiros, 2019). 
Perhaps because available evidence on public-private ownership and costs/efficiency is so consistent, greater emphasis has been placed in recent studies on the relationship between the production form and user prices. Here, outcomes are more varied, although most analyses find that private management is associated with higher prices than those charged by public firms. Most studies conducted have been done so in Spain and France, which is consistent with the fact that these are the two European countries with publicly owned water networks in which private delivery also enjoys a high rate of participation. In both countries, private companies tend to charge higher prices than those charged by public production (for France, see Carpentier et al., 2006; Chong et al., 2006; for Spain, see Martínez-Espiñeira, García-Valiñas and González-Gómez, 2009).

However, in the case of France, several studies suggest that this price differential is only relevant in the case of small municipalities, and not in that of their larger counterparts (Chong, Saussier and Silverman, 2015; Porcher and Saussier, 2018). Furthermore, in an interesting study by Valero (2015), the relationship between prices and the form of production (public vs. private) is controlled precisely for the endogeneity of the choice of this production, the author finding that the higher prices charged under private management are a consequence of idiosyncratic factors related to costs (private management being chosen for more complex service conditions), rather than of the form of production itself.

Outside France and Spain, private management is associated with higher prices in countries such as England and Wales (Saal and Parker, 2001; recall that network ownership there is private as well), Germany (Ruester and Zschille, 2010), Portugal (Silvestre and Gomes, 2017), and several countries in Latin America (Andrés et al., 2008). Note as well that a few studies, specifically for North Carolina and for Italy, did not find any differences in price (GonzálezGómez and García-Rubio, 2018). It is interesting to note that in the case of Italy, Romano, Masserini and Guerrini (2015) control for choice of production form in the same way as Valero (2015) did for France.

\section{Effects on quality and accessibility}

Research on the consequences of the privatization of water services has paid increasing attention to their impact on accessibility and affordability. Evidence here remains scarce and mixed, and heavily focused on Latin American countries, above all, Bolivia and Argentina, where privatization was later followed by renationalization. McKenzie and Mookherjee (2002), Galiani et al. (2005) and De Oliveira (2008) find increasing coverage with private management in, respectively, Bolivia, Argentina and Brazil, while Clarke, Kosec and Wallsten (2009) find no significant impact of private management in these three countries. Outside Latin America, Lee (2011) reports the negative impact of private management on access and affordability in Malaysia.

Finally, there is some evidence regarding the relationship between private management and quality. Porcher and Saussier (2018) report a set of econometric studies conducted for France and the US. While the studies for France point to an improvement in water quality, the results for the US are contradictory and do not allow any clear conclusions to be drawn.

\section{5.- Drivers of remunicipalization of water services}

Evidence regarding the drivers of the remunicipalization of public services has been provided mainly by case studies, such as those conducted for water services in the Bolivian cities of Cochabamba and El Alto-La Paz (Nickson and Vargas, 2002; Slattery 2003) and in the 
Argentinian cities in the province of San Rafael, Buenos Aires and Córdoba (Baer and Montes-Rojas, 2008; Manzeti, 2016). In these cases, specific issues related to contract failures and price increases triggered remunicipalization. For Europe, Hall, Lobina and Terhorst (2013: 199-200) have studied the remunicipalization of water services in Paris and Grenoble, identifying as drivers issues such as the mistrust of private firms due to overpricing and corruption, as well as political pressure from 'green' politicians and activists.

Beyond these case studies and anecdotal evidence, analyses based on large samples and employing multivariate statistical techniques remain scarce. Several multi-service studies have been conducted for the US (Warner and Hebdon, 2001; Hefetz and Warner, 2004, 2007, 2012; and Warner and Aldag, forthcoming), tending to conclude that reverse privatization is a pragmatic decision rather than a political or ideological one. For the Netherlands, Gradus and Budding (forthcoming) study the remunicipalization of solid waste collection and report the slight influence of ideological factors.

In the specific instance of the remunicipalization of water, two studies are available in the literature. Campos-Alba et al. (2017) conduct a separate analysis of several local services in Spain, among them water, and find that water - in common with other technical services is less frequently remunicipalized than personal services (contradicting data reported by Albalate and Bel, forthcoming), and that remunicipalization decisions are pragmatic rather than ideological. The most complete study on water to date is Chong, Saussier and Silverman (2015), who analyze water prices under private and public management and the drivers of remunicipalization. They find that prices tend to be higher under private management, especially in municipalities below 10,000 inhabitants. Furthermore, they find that smaller municipalities with private management and an overpriced service tend to switch private providers, whereas larger municipalities with an overpriced service tend to remunicipalize. However, ideology does not appear to be a relevant factor.

\section{6.- Effects of remunicipalization. What to expect?}

No robust evidence is yet available on the effects of the remunicipalization on different dimensions of water services, and the debate on this question has been largely dominated to date by anecdotal evidence and politically grounded assessments. However, by taking into account what the effects of water privatization were in the past, we can derive certain indications as to what the effects might be of water remunicipalization.

First, recall that neither service quality nor accessibility and affordability were negatively correlated with private management; therefore, we should not expect relevant changes in these dimensions of the service following remunicipalization. Likewise, no relevant systematic effects on efficiency should be expected, as efficiency under private management did not appear to be systematically different from efficiency under public management. Transparency and corruption, however, should be a different story, given that they have been strong drivers of remunicipalization in such cases as that of Grenoble. As Hart, Shleifer and Vishny (1997) point out, rent-seeking politicians tend to engage in patronage and overemployment with public production, and to use private production to obtain material rents. Therefore, remunicipalization should reduce concerns about corruption, but care should be taken not to increase political patronage following remunicipalization.

The effects of remunicipalization on water prices are more complex to estimate, given that higher prices under private management have been an influential driver of remunicipalization. On the one hand, municipalities such as Paris lowered their water prices 
immediately after remunicipalization (Le Strat, 2010). Yet, other assessments suggest that investment after remunicipalization is significantly lower than it was under private operation (Schiffler, 2015). A recent study by Chabrost, Porcher and Saussier (2017) conducted with hundreds of French cities should shed some light in this regard. Indeed, the authors find that the price of water distribution is significantly higher under private management, but that water leaks are significantly higher under public management, which would suggest underinvestment with public delivery. ${ }^{1}$ Hence, if cutting investment is indeed the consequence of reducing prices after remunicipalization, lower prices may not be sustainable over time.

It is well known that in sectors subject to regulation and in which competition is weak, prices do not necessarily reflect costs. In fact, prices may differ substantially from costs. Water distribution is one such sector. This means that the differences in prices between private and public management may well simply be hiding different policies with regard to cost recovery via revenues. Porcher (2017) studies prices in the water sector in France and finds - as usual - that prices are higher under private management, but that this difference disappears when accounting for what Porcher calls the 'hidden costs' of water: that is, "the price taking into consideration debt refunding of the public service which could increase the price in the following years" (Porcher, 2017: 166). His empirical analysis shows that under private delivery tariffs are higher, but debt level is lower; thus, price follows the full-cost recovery criterion more closely under private management, whereas under public management prices are lower but debt is higher.

While Porcher's (2017) is the only study of the 'hidden costs' of the water service of which we are aware, it is worth noting that his results are consistent with those found by Bel and Miralles (2010) for solid waste collection in Catalonia (Spain). These authors compare revenues from fees for solid waste collection and the costs incurred for the service under public and private management and find that municipalities with private management charge higher rates for the service, but have a lower service-related deficit. That is, budget subsidies to the service are significantly higher under public management. Based on their results, Bel and Miralles suggest that privatization may have been used as a tool to reduce public deficit by means of increasing cost recovery through higher user payments. ${ }^{2}$

\section{7.- Final remarks}

Remunicipalization has become something of a controversial issue in recent years, although its practice has not increased as much as was expected following the well-known cases of water remunicipalization in Paris and Berlin. The analysis of municipalization in historical perspective offers us some insights that are useful for understanding the drivers of water municipalization in recent decades. Concerns with overpricing and corruption under private management emerge as the most influential factors behind remunicipalization, while ideological pressures seem to play a much less relevant role. In this regard, the public interest

\footnotetext{
${ }^{1}$ Political dynamics at play can also be interpreted here: municipalities needing important investments tend to involve the private sector, to let it make investments and increase water prices correspondingly. In that way, customers will put the blame of price increases on the private sector. ${ }^{2}$ In this regard, it is interesting to note that in Italy in 2008 the Galli reform was introduced with the objective of promoting the private management of water delivery, including the criteria of full cost recovery and consolidation of services at the provincial level. The associated suppression of subsidies would have caused a sharp increase in user prices, which led to social discontent and the rejection of the Galli reform in a later referendum. I owe this suggestion to a referee. See Massarutto (2012) for an analysis of the water sector reform in Italy.
} 
approach seems to be more useful than that of the private interest for explaining privatization. Systematic evidence on the economic effects of remunicipalization is extremely scarce. Note, however, that investment seems to fall after remunicipalization, contrary to what occurred in the Progressive Era in the US.

A study of contractual and transaction costs also sheds some light on the drivers of remunicipalization. Public concerns with regard to relatively high prices under private delivery can be addressed by means of higher budget subsidies to the service, but this is more politically viable under public than under private management. As such, this could trigger remunicipalization.

Existing evidence on 'hidden costs' (be it based on lowering investments or increasing debt) and budget subsidies to cover the operational costs of the service, although still scarce, cast reasonable doubt on whether immediate price reductions after the remunicipalization of water services are sustainable over time. Clearly, this is one of the most controversial issues regarding the effects of water municipalization and tariffs and more research will undoubtedly be devoted to clarifying matters.

Acknowledgments: This research benefited from financial support from the Spanish Ministry of Economy and Competitiveness (ECO2016-76866-R) and from the Government of Catalonia (2017 SGR644). No sponsor was involved in the design and implementation of the research. Comments and suggestions received at the Conference on Sustainable Tariffs for Water Services (Lisbon, March 2019) have been very useful, as well as suggestions from two anonymous referees.

\section{References}

Adler, Moshe, 1999. Been there, done that: The privatization of street cleaning in nineteenth century New York. The New Labor Forum, Spring: 88-99.

Albalate, Daniel, Bel, Germà, forthcoming. Politicians, bureaucrats and the publicprivate choice in public service delivery: Anybody there pushing for remunicipalization? Journal of Economic Policy Reform forthcoming

Andrés, Luis A., Guasch, J. Luis, Haven, Thomas, Foster, Vivien, 2008 The impact of private sector participation in infrastructure: Lights, shadows and the road abead. World Bank: Washington DC.

Aubin, David, 2003. Belgium. In Mohajeri, Shahrooz, Knothe, Bettina, Lamothe David Nicolas, Faby, Jean-Antoine, eds., Aqualibrium. European water management between regulation and competition. European Commission, Brussels, pp. 49-68.

Baer, Werner, Montes-Rojas, Gabriel, 2008. From Privatization to Re-nationalization: What went Wrong with Privatizations in Argentina? Oxford Development Studies 36 (3): 323337.

Barraqué, Bernard \& Kraemer, R. Andreas. 2014. Les services publics d'eau en GrandeBretagne et en Allemagne: origine commune, trajectoires différentes. Flux 97-98(3): 16-29.

Bel, Germà, Fageda, Xavier, 2007. Why do local governments privatize local services? A survey of empirical studies. Local Government Studies 33 (4): 517-534.

Bel, Germà, Fageda, Xavier, 2009. Factors explaining local privatization: a meta-regression analysis. Public Choice 139(1): 105-119.

Bel, Germà, Fageda, Xavier, 2017. What have we learned from the last three decades of empirical studies on factors driving local privatisation? Local Government Studies 43(4): 503-511. 
Bel, Germà, Fageda, Xavier, Warner, Mildred. 2010. Is Private Production of Public Services Cheaper than Public Production? A meta-regression analysis of solid waste and water services. Journal of Policy Analysis and Management, 29(3): 553-577

Bel, Germà, Miralles, Antonio, 2010. Choosing between service fees and budget funding to pay for local services: Empirical evidence from Spain. Environment and Planning C: Government and Policy; 28(1): 54-71.

Bel, Germà, Sebö, Marianna, forthcoming. Does inter-municipal cooperation really reduce delivery costs? an empirical evaluation of the role of scale economies, transaction costs, and governance arrangements. Urban Affairs Review, forthcoming

Bel, Germà, Warner, Mildred, 2008. Does privatization of solid waste and water services reduce costs? A review of empirical studies. Resources, Conservation \& Recycling 52(12): 1337-1348

Bel, Germà, Warner, Mildred, 2015. Inter-municipal cooperation and costs: Expectations and evidence. Public Administration 93(1): 52-67.

Bel, Germà, Warner, Mildred, 2016. Factors explaining inter-municipal cooperation in service delivery: A Meta-regression analysis. Journal of Economic Policy Reform 19(2): 91115.

Bhatti, Yosef, Olsen, Asmus L, Pedersen, Lene H. 2009. The Effects of Administrative Professionals on Contracting Out. Governance 22(1): 121-137.

Bönker, Frank, Libbe, Jens, Wollmann, Helmuth. 2016. Remunicipalisation revisited: longterm trends in the provision of local public services in Germany. In Wollmann, Hellmut, Koprić, Ivan, Marcou, Gérard, eds. Public and Social Services in Europe. From Public and Municipal to Private Sector Provision. Palgrave Macmillan, London, pp. 71-85.

Campos-Alba, Cristina, Higuera-Molina, Emilio, Pérez-López, Gemma, Zafra-Gómez, José L., 2017. Explanatory factors in the renewal of contracts for the privatisation of public services. Journal of Strategic Contracting and Negotiation 3(1): 3-19.

Carpentier Alain, Nauges, Céline, Reynaud, Arnaud, Thomas, Alban. 2006. Effets de la delegation sur le prix de l'eau potable en France. Une analyse à partir de la littérature sur les effets de traitement. Économie et prévision, 174: 1-19.

Carvalho, Pedro, Pedro, Isabel, Marques, Rui C., 2015. The most efficient clusters of Brazilian water companies. Water Policy 17(5): 902-917.

Cetrulo, Tiago B., Marques, Rui C., Malheiros, Tadeu F., 2019. An analytical review of the efficiency of water and sanitation utilities in developing countries. Water Research 162: 372-380.

Chabrost, Marion, Porcher, Simon, Saussier, Stéphane, 2017. Get what you pay for. The story underneath remunicipalisation in the water sector. Paper presented at $6^{\text {th }}$ Conference on the regulation of infrastructures: regulatory challenges for smart cities. European University Institute. Firenze, 16 June 2017.

Chong Eshin., Huet Freddy, Saussier Stéphane, Steiner Faye. 2006. Public Private Partnerships and prices: Evidence from water distribution in France. Review of Industrial Organization 29(12), 149-169.

Chong, Eshien, Saussier, Stéphane, Silverman, Brian, 2015. Water Under the Bridge: Determinants of Franchise Renewal in Water Provision. Journal of Law, Economics, and Organization 31 (suppl 1): i3-i39.

Clarke, George R.G., Kosec, Katrina, Wallsten, Scott, 2009. Has private participation in water and sewerage improved coverage? Empirical evidence from Latin America. Journal of International Development 21(3): 327-361.

Cutler, David, Miller, Grant, 2005. Water, water, everywhere: Municipal finance and water supply in American cities. NBER WP 11096 National Bureau of Economic Research, Washington, D.C. 
Elinder Mikael, Jordahl, Henrik, 2013. Political preferences and public sector outsourcing. European Journal of Political Economy 30: 43-57.

Galiani, Sebastian, Gertler, Paul, Schargrodsky, Ernesto, 2005. Water for life: The impact of the privatization of water services on child mortality. Journal of Political Economy, 113(1): 83-120.

Gómez-lbáñez, José A., 2003. Regulating infrastructure. Monopoly, contracts and discretion. Harvard University Press, Cambridge, MA.

González-Gómez, Francisco, García-Rubio, Miguel A., 2018. Prices and ownership in the water urban supply: a critical review. Urban Water Journal 15(3): 259-268

Gradus, Raymond, Budding, Tjerk, forthcoming. Political and Institutional Explanations for Increasing Re-municipalization. Urban Affairs Review forthcoming.

Guo, Ming, Willner, Sam, 2017. Swedish politicians' preferences regarding the privatisation of elderly care. Local Government Studies 43(1): 1-21.

Hall, David, Lobina, Emanuele, Terhorst, Phillip. 2013. Re-municipalisation in the Early Twenty-First Century: Water in France and Energy in Germany. International Review of Applied Economics 27(2): 193-214.

Hart, Oliver, Shleifer, Andrei, Vishny, Robert W., 1997. The Proper scope of government: Theory and an application to prisons. Quarterly Journal of Economics 112(4): 1127-1161.

Hefetz, Amir, Warner, Mildred. 2004. Privatization and its reverse: Explaining the dynamics of the government contracting process. Journal of Public Administration Research and Theory 14(2): 171-190.

Hefetz, Amir, Warner, Mildred, 2007. Beyond the Market Versus Planning Dichotomy: Understanding Privatisation and its Reverse in US cities." Local Government Studies 33 (4): 555-572.

Hefetz, Amir, Warner, Mildred, 2012. Contracting or Public Delivery? The Importance of Service, Market and Management Characteristics. Journal of Public Administration Research and Theory 22(2): 289-317.

Hefetz, Amir, Warner, Mildred, Vigoda-Gadot, Eran. 2012. Privatization and intermunicipal contracting: the US local government experience 1992-2007. Environment and Planning C: Government and Policy 30(4): 675 - 692

Jacobson, Charles D., 2000. Ties that bind. Economic and political dilemmas of urban utility networks 1800-1990. University of Pittsburgh Press, Pittsburgh, PA.

Jacobson, Charles D., Tarr, Joel A., 1995. Ownership and Financing of Infrastructure: Historical Perspectives. The World Bank, Policy Research Working Paper Series, 1466, Washington, D.C.

Le Strat, Anne, 2010. Paris: local authorities regain control of water management. Transnational Institute. https://www.tni.org/en/article/paris-local-authorities-regain-control-ofwater-management (Downloaded May 10, 2019)

Lee, Cassey, 2011. Privatization, water access and affordability: Evidence from Malaysian household expenditure data. Economic Modelling 28(5): 2121-2128

Lough, Alexandra, W., 2016. The Politics of Urban Reform in the Gilded Age and Progressive Era, 1870-1920. American Journal of Economics and Sociology 75(1): 8-22.

Manzetti, Luigi, 2016. Renationalization in Argentina, 2005-2013. Latin American Politics and Society 58(1): 3-28.

Martínez-Espiñeira, Roberto, García-Valiñas, María A., González-Gómez, Francisco. 2009. Does Private Management of Water Supply Services Really Increase Prices? An Empirical Analysis in Spain. Urban Studies 46(4), 923-945

Massarutto, Antonio, 2012. "Urban water conflicts and sustainability: An ecologicaleconomic approach", in: Barraqué, Bernard (ed.). Urban Water Conflicts. London: UNESCO-IHP. CRC Press. Taylor \& Francis, pp. 285-309. 
McDonald, David A. 2018. Remunicipalization: The future of water services? Geoforum, 91: 47-56.

McKenzie, David, Mookherjee, Dilip, 2003. The distributive impact of privatization in Latin America: Evidence from Four Countries. Economia. Journal of the Latin American and Caribbean Economic Association 3(2): 161-234.

Melosi, Martin V., 1981. Garbage in the cities. Refuse, reform, and the environment, 1880-1980. College Station (TX): Texas A\&M University Press.

Melosi, Martin V. 2012. "Full circle? Public responsibility versus privatization of water supplies in the United States.", in: Barraqué, Bernard (ed.). Urban Water Conflicts. London: UNESCO-IHP. CRC Press. Taylor \& Francis, pp. 39-56.

Millward, Robert. 2007. La distribution de l'eau dans les villes en Grande Bretagne au XIXe et XXe siècles: le gouvernement municipal et le dilemme des compagnies privées. Histoire, économie \&s société, 26(2): 111-128.

Nickson, Andrew, Vargas, Claudia, 2002. The Limitations of Water Regulation: The Failure of the Cochabamba Concession in Bolivia. Bulletin of Latin American Research, 21(1): 128-149.

Núñez Romero-Balmas, Gregorio. 1996. "Servicios urbanos colectivos en España durante la segunda industrialización: entre la empresa privada y la gestión pública", in Comín, Francisco, Martín Aceña, Pablo. eds., La empresa en la Historia de España. Madrid: Civitas, pp. 399-419

Oliveira, Andre R de, 2008. Private Provision of Water Service in Brazil: Impacts on Access and Affordability. MPRA Paper 11149, University Library of Munich, Germany

Peltzman, Sam, 1976. Toward a more general theory of regulation. Journal of Law and Economics 19(2): 211-240.

Petersen, Ole H., Hjelmar, Ulf, Vrangbæk, Karsten. 2018. Is Contracting out of Public Services still the Great Panacea? A Systematic Review of Studies on Economic and Quality Effects from 2000 to 2014. Social Policy and Administration, 52(1): 130-157.

Petersen, Ole H., Houlberg, Kurt, Christenssen, Lasse R., 2015, Contracting Out Local Services: A Tale of Technical and Social Services. Public Administration Review 75(4): 560-570

Pezon, Christelle, 1999. La gestion du service d'eau potable en France de 1850 à 1995. Ph. D. Dissertation. Paris: Conservatoire National des Arts et des Métiers.

Pezon, Christelle. 2010. How the Compagnie Générale des Eaux survived the end of concession contracts in France 100 years ago. Water Policy 13(2): 178-186.

Pezon, Christelle, 2012. "Public-private partnerships in courts: the rise and fall of concessions to supply drinking water in France, 1875-1928", in: Barraqué, Bernard (ed.). Urban Water Conflicts. London: UNESCO-IHP. CRC Press. Taylor \& Francis, pp. 57-68.

Porcher, Simon. 2017. The 'hidden costs' of water provision: New evidence from the relationship between contracting-out and price in French water public services. Utilities Policy 48: 166-175.

Porcher, Simon, Saussier, Stéphane, 2018. Public versus private management in water public services: taking stock, looking ahead. WP EUI RSCAS; 2018/64; Florence School of Regulation

Posner, Richard A., 1974. Theories of economic regulation. Bell Journal of Economics and Management Science 5(2): 335-358.

Posner, Richard A., 1975. The social costs of monopoly and regulation. Journal of Political Economy 83(4): 807-827.

Romano, Giulia, Masserini, Lucio, Guerrini, Andrea. 2015. Does water utilities' ownership matter in water pricing policy? An analysis of endogenous and environmental determinants of water tariffs in Italy. Water Policy 17(5): 918-931. 
Roth, Gabriel J., 1987. The Private Provision of Public Services in Developing Countries. Oxford: Oxford University Press.

Ruester, Sophia, Zschille, Michael, 2010. The impact of governance structure on firm performance: An application to the German water distribution sector. Utilities Policy 18(3): 154-162.

Saal, David S., Parker, David, 2001 Productivity and price performance in the privatized water and sewerage companies of England and Wales. Journal of Regulatory Economics 20(1): 61-90.

Schiffler, Manuel, 2015. Water, Politics and Money. A Reality Check on Privatization. Springer

Silvestre, Hugo C., Gomes, Ricardo C. 2017. A resource-based view of utilities: The keydeterminant factors for customer prices and organizational costs in the Portuguese water industry. Water Resources and Economics 19: 41-50

Silvestre, Hugo C., Marques, Rui C., Gomes, Ricardo C. 2018. Joined-up Government of utilities: a meta-review on a public-public partnership and inter-municipal cooperation in the water and wastewater industries, Public Management Review 20(4): 607-631

Slattery, Kathleen, 2003. What went wrong? Lessons from Cochabamba, Manila, Buenos Aires and Atlanta. In Balaker, Ted, ed., Annual privatization Report 2003. Washington DC: Reason Foundation.

Stigler, George J., 1971. The theory of economic regulation. Bell Journal of Economics and Management Science 2(1): 3-21.

Troesken, Werner, 1997. The sources of public ownership: Historical evidence from the gas industry. Journal of Law, Economics \& Organization, 13(1): 1-25.

Troesken, Werner, 1999. Typhoid rates and the public acquisition of private waterworks, 1880-1920. Journal of Economic History 59(4): 927-948.

Troesken, Werner, 2001. Race, disease, and the provision of water in American Cities, 18891921. Journal of Economic History 61(3): 750-776.

Troesken, Werner, 2002. The limits of Jim Crow: Race and the provision of water and sewerage services in American cities, 1880-1925. Journal of Economic History 62(3): 734772 .

Troesken, Werner, Geddes, Rick, 2003. Municipalizing American waterworks, 1897-1915. Journal of Law, Economics \& Organization 19(2): 373-400.

Tynan, Nicola, 2001. The Private Provision of Water: Lessons from the London Experience, $1582-$ 1902. PhD Dissertation. George Mason University.

Valero, Vanessa. 2015/6. Les écarts de prix de l'eau en France entre les secteurs privé et public. Revue économique 66: 1045-1066.

Warner, Mildred, Aldag, Austin. forthcoming. Re-municipalization in the US: A Pragmatic Response to Contracting. Journal of Economic Policy Reform forthcoming.

Warner, Mildred, Hebdon, Robert. 2001. Local government restructuring: privatization and its alternatives. Journal of Policy Analysis and Management 20(2): 315-336

Wollmann, Helmut. 2016. "Provision of Public and Social Services in European Countries: From Public Sector to Marketization and Reverse-or, What Next?", in Kuhlmann, Sabine, Bouckaert, Geert, eds. 2016. Local Public Sector Reforms in Times of Crisis. National Trajectories and International Comparisons. London: Palgrave Macmillan, pp. 187-204.

Wollmann, Helmut. 2018. Public and Personal Social Services in European Countries from Public/Municipal to Private-and Back to Municipal and "Third Sector" Provision. International Public Management Journal 21(3): 413-431. 